\title{
The sacrosanct? The challenge in holding the United Nations responsible for the failure to prevent genocide
}

\author{
Allan Mukuki*
}

\section{Abstract}

States are collapsing and genocidal acts are being committed or may happen any moment. In these instances, states look to the United Nations (UN) to act in order to prevent genocide from happening. This article seeks to determine if there exists an obligation under international law for the UN to prevent genocide, and in that event, can the UN be held responsible under international law for failure to comply with this obligation? This article further analyses these questions by looking at the aspect of Responsibility to Protect (R2P) which elicits an obligation to prevent genocide first to states and then to the UN. At the very minimum, every state must protect its population from genocide, war crimes, ethnic cleansing and crimes against humanity. In the case of states failing to undertake this obligation, the UN is bound to step in and undertake this obligation. Hence, this is a responsibility that is an obligation to states first and then to the UN. In summation, this article establishes that the obligation to prevent genocide is a customary international law obligation. Further, the UN is bound by this obligation. However, it is shown that the procedures that are available to address its failure to uphold this obligation are inconsequential since the UN has absolute immunity and any decision, even if holding the UN responsible, cannot be enforced as against it. Neverthless, this article provides some recommendation(s) as to how the UN can play a role in ensuring accountability for failures within its ambit.

* The author teaches at Strathmore Law School. 


\section{Introduction}

The focus of this article is not whether acts of genocide are currently taking place. Therefore, it does not analyse the current situation in the various regions where genocidal acts are said to be occurring. It does not also provide any conclusions as to whether or not any such acts are currently taking place.

This article does not engage either in the discussion of 'potential developments' in terms of the accountability of the United Nations (UN) in peacekeeping operations, and developments on the same. None of these is relevant at this point in time since it would be more relevant to discuss if the topic was more related to future developments.

Rather, this article looks at the key definitions in relation to genocide. These terms are 'genocide', 'international legal responsibility', 'responsibility to protect (R2P)' and finally 'failure to prevent'. The definition of these terms is made in a bid to understand the meanings and controversies that have arisen in their relation.

Further, an analysis of the obligation to prevent genocide is undertaken. This is to show that indeed this obligation is one that is entrenched in customary international law (CIL). The obligation to prevent genocide is then analysed against its relationship with the international legal responsibility of states and the $\mathrm{UN}$ and in relation to $\mathrm{R} 2 \mathrm{P}$.

Thereafter, this article analyses whether the UN is bound by the obligation to prevent genocide. Select instances in which the UN is deemed to have failed to prevent genocide are also analysed vis-à-vis the relevant case law. This then leads to a discussion of the UN responsibility for failure to prevent genocide under international law as well as the procedure available to hold the UN responsible for this failure. An argument is made that although the UN can be held responsible for failure to prevent genocide, but the ensuing decision cannot be upheld against it due to the absolute immunity that it possesses under international law.

\section{Definition of key terms}

\section{Genocide}

In defining genocide, this article only offers a broad overview in order to provide the necessary understanding of the term with regard to the topic at hand 
- in the context of prevention. Importantly, in order to gain a full understanding of the concept of genocide, four elements should be examined, namely: (1) what are considered acts of genocide?; (2) the selective protection of groups; (3) the destruction of a group 'in whole or in part'; and (4) genocidal intent. However, such an extensive judicial definitional approach to these elements goes beyond the scope of this paper.

\section{A conventional definitional approach}

The Convention on the Prevention and Punishment of the Crime of Genocide (Genocide Convention) defines genocide in Article 2 as

[a]ny of the following acts committed with the intent to destroy, in whole or in part, a national, ethnical, racial or religious group, as such:

(a) Killing members of the group;

(b) Causing serious bodily or mental harm to members of the group;

(c) Deliberately inflicting on the group conditions of life calculated to bring about its physical destruction in whole or in part;

(d) Imposing measures intended to prevent births within the group; and

(e) Forcibly transferring children of the group to another group. ${ }^{1}$

Article 3 of the Genocide Convention stipulates which acts are punishable. These include; Genocide; conspiracy to commit genocide; direct and public incitement to commit genocide; attempt to commit genocide; and complicity in genocide. $^{2}$

In an effort to briefly summarise the concept of genocide reliance on the UN General Assembly (UNGA) Resolution 96(I), adopted in 1946, is important and it states that,

Genocide is a denial of right of existence of entire human groups, as homicide is a denial of the right to life of individual human beings; such denial of right of existence shocks the conscience of mankind, results in great losses to humanity in the form of cultural and other contributions represented by these human groups, and is contrary to moral law and to the spirit and aims of the United Nations. Many instances of such crimes of genocide have occurred when racial, religious, political and other groups have been destroyed, entirely or in part. The punishment of the crime of genocide is a matter of international concern... ${ }^{3}$

1 Article 2, Convention on the prevention and punishment of the crime of genocide, 9 December 1948, 78 UNTS 277 (Genocide Convention). Emphasis added.

Article 3, Genocide Convention.

UNGA, Prevention and punishment of the crime of genocide, UN A/RES/260 (9 December 1948). 
Furthermore, in the Resolution, the UNGA affirmed that:

[g]enocide is a crime under international law which the civilised world condemns, and for the commission of which principals and accomplices -whether private individuals, public officials or statesmen, and whether the crime is committed on religious, racial, political or any other grounds- are punishable...

Through this Resolution, UNGA invited the member states to enact the necessary legislation for the prevention and punishment of genocide. ${ }^{4}$

While it is clear that within the context and circumstances surrounding the adoption of the Genocide Convention, namely, in the aftermath of World War II, emphasis was put on criminalising genocide, the Genocide Convention focuses more on punishment, rather than prevention, and offers no clear definition of what prevention actually entails. Nevertheless, the Convention still stipulates an obligation on states to prevent the crime of genocide. ${ }^{5}$ Article 1 of the Convention makes this clear by stipulating that, ' $[\mathrm{t}]$ he Contracting Parties confirm that genocide, whether committed in time of peace or in time of war, is a crime under international law which they undertake to prevent and to punish. ${ }^{6}$

Importantly, the obligation to prevent should be seen as separate from the obligation to punish genocide. While the International Court of Justice (ICJ) has recognised that, 'the most effective way of preventing criminal acts, in general, is to provide penalties for the persons committing such acts, and to impose those penalties effectively on those who commit the acts one is trying to prevent, ${ }^{77}$ the two obligations must still be seen as existing independently. The ICJ, in the Bosnia $v$ Serbia case, ${ }^{8}$ confirmed this point of view, when it held that:

[t] he obligation on each contracting state to prevent genocide is both normative and compelling. It has not merged with the duty to punish, nor can it be regarded as simply a component of that duty. It has its own scope, which extends beyond the particular case envisaged in Article VIII, namely “....reference to the competent organs of the United Nations, for them to take such action as they deem appropriate." Furthermore, the title of the Convention reads "Convention on the Prevention and Punishment of the Crime of Genocide. ${ }^{10}$

UNGA, Prevention and punishment of the crime of genocide.

5 Ruvebana E, Prevention of genocide under international law: An analysis of the obligations of states and the United Nations to prevent genocide at the primary, secondary and tertiary levels, Intersentia, Publishing Ltd, Cambidge, 2014, 86-93.

Article 1, Genocide Convention.

Application of the Convention on the Prevention and Punishment of the Crime of Genocide (Bosnia and Herzegovina v Serbia and Montenegro), Judgment, ICJ Reports, 2007, 43, para 426.

Bosnia and Herzegovina v Serbia and Montenegro, ICJ, para 426.

Bosnia and Herzegovina v Serbia and Montenegro, ICJ, para 427.

Genocide Convention. 
The above statement indicates that it was created not only to punish those who have committed the crime of genocide, but also to prevent it. In the end, the obligation to prevent genocide should be seen as putting in place measures that prevent the occurrence of harm, whereas the obligation to punish genocide arises after the harm has occurred. Thus, the obligation to punish may act as a deterrence mechanism with regard to future genocides, but only really comes into play after the obligation to prevent has not been complied with. ${ }^{11}$

\section{International legal responsibility}

Responsibility plays an important role in international law. According to Paul Reuter, '[r] esponsibility is at the heart of international law (...) it constitutes an essential part of what may be considered the Constitution of the international community. ${ }^{12}$ In other words, it is an essential ingredient or requirement in the establishment of accountability. ${ }^{13}$

Traditionally, public international law was the exclusive domain of states and only states could incur international responsibility under international law. Bearing in mind that all sovereign states are equal in right as well as in their corresponding duties to respect the rights of other sovereign states, ${ }^{14}$ it therefore holds that if a sovereign state violates, fails or is unwilling to fulfill its obligations under international law, it should be held accountable. In August 2001, the International Law Commission (ILC) ${ }^{15}$ adopted and codified the rules on state responsibility into the Draft Articles on Responsibility of States for Internationally Wrongful Acts (ASR), ${ }^{16}$ parts of which can be deduced to be rules of CIL and, thus, it could be argued that it imposes binding obligation upon all states. ${ }^{17}$

11 Ruvebana E, Prevention of genocide under international law, 103-105.

12 Reuter P, 'Trois observations sur la codification de la responsabilité internationale des États pour fait illicite' in Le droit international au service de la paix, de la justice et du development: mélanges Michel Virally, Pedone, Paris 1991, 390, 574.

13 Nollkaemper A, 'Dual attribution: Liability of the Netherlands for conduct of Dutchbat in Srebrenica' 9(5) Journal of International Criminal Justice, 2011, 1143-1157. See also Nollkaemper A, 'Issues of shared responsibility before the International Court of Justice' Amsterdam Law School Research Paper No 2011-01.

14 Montevideo Convention on Rights and Duties of States (1993) 165 LNTS 19.

15 Draft articles on responsibility of states for internationally wrongful acts, ILC $53^{\text {rd }}$ Report, 2001, UN Doc A/56/10.

16 ILC, Draft articles on responsibility of states for internationally wrongful acts.

17 See ILC, Draft articles on responsibility of states for internationally wrongful acts, with commentaries, November 2001, General Commentary, para 1 \& 4(a). 
Interestingly, the monopoly of states as the only subject of international law has shifted drastically with the recognition of certain entities as having international legal personality. ${ }^{18}$ Apparently, international responsibility may only be incurred by an entity that possesses international legal personality. The question worth asking is; does an international organisation have international legal personality in order to qualify as a subject of international law? In the Reparation Advisory Opinion, the ICJ came to the conclusion that the UN possesses international legal personality and, as such, was a subject of international law from which rights and obligations flow. ${ }^{19}$ The ICJ further pointed out that the UN, having international legal personality, can engage in its own responsibility as well as invoke the responsibility of states. From the decisions of the ICJ, it is evident that the UN can bring claims if its interest is at stake, and at the same time could be liable for injuries inflicted on third parties, such as in peace-keeping operations (such as in Kosovo and East Timor).

One may argue that the same consequences that flow from the breach of an international obligation by states should also be extended to international organisations. ${ }^{20}$ This does not in any way suggest that both states and international organisations have the same rights and duties under international law; far from it, some authors have argued that, 'the mechanisms of responsibility which are applicable to states may not necessarily be transposed wholesale and unmodified to international organisations. ${ }^{21}$ The basis for this line of argumentation is the distinction between the $\mathrm{ASR}^{22}$ and the Draft Articles on the Responsibility of In-

18 Reparation for injuries suffered in the service of the United Nations, Advisory Opinions, ICJ Reports,1949, 174, 179.

19 Reparation for injuries suffered, ICJ: 'the [United Nations] is an international person', principally because 'its members, by entrusting certain functions to it, with the attendant duties and responsibilities, have clothed it with the competence required to enable those functions to be effectively discharged.' See also, Interpretation of the Agreement of 25 March 1951 between the WHO and Egypt, Advisory Opinion, ICJ Reports 1980, 73, para 37. Legality of the threat or use of nuclear weapons, Advisory Opinion, ICJ Reports, 1996, 226, para 25. Difference relating to immunity from legal process of a Special Rapporteur of the Commission on Human Rights, Advisory Opinion, ICJ Reports, 1999, 62, para 66.

20 Klein P, La responsabilité des organisation intenationales dan les ordres juridiques internes et en droit des gens, Éditions Bruylant, Bruxelles, 1998, 305.

21 Pellet A, 'The definition of responsibility in international law' in Crawford J, Pellet A, Olleson S (eds), The law of international responsibility, Oxford University Press, Oxford, 2010. According to Pellet, 'two elements prevent a pure transposition: on the one hand, the principle of speciality which characterises (and limits) the competencies of international organizations; and, on the other, the limited concrete resources (including financial resources) which international organizations have available to deal with the obligations resulting from the engagement of their responsibility.'

22 UNGA, Responsibility of states for internationally wrongful acts, UN A/56/83 (28 January 2002). 
ternational Organisations (DARIO) ${ }^{23}$ While the ASR governs the responsibility of states under international law, DARIO focuses primarily on the responsibility of international organisations. ${ }^{24}$

In this same line of thought, the $\mathrm{UN}$ as an international organisation, just like any other such entity, cannot be held to have exactly the same responsibilities as states. Hence, the rules need to be adjusted to take into account the differences between this particular international organisation and states. The discourse regarding which adjustments are necessary is beyond the scope of this article and so will not be discussed.

Nevertheless, when it comes to the ASR as codified by the ILC, the Articles that deal with the international responsibility of states are Article 1 and 2.Article 1 provides: Every internationally wrongful act of a state entails the international responsibility of that state.' Article 2 continues that; 'There is an internationally wrongful act of a state when conduct consisting of an action or omission: (a) is attributable to the state under international law; and (b) constitutes a breach of an international obligation of the state. ${ }^{25}$

Evidently, the international responsibility of a state is triggered when an internationally wrongful act is committed by organs or persons, which consists of conduct that is attributable to a state under international law, that is, conduct over which states exercise effective control. ${ }^{26}$

On its part, the DARIO was adopted by the ILC in August 2011. ${ }^{27}$ It deals only with legal responsibility of international organisations. Part 1 of DARIO provides under Article 1 that; The present draft articles apply to the international responsibility of an international organisation for an internationally wrongful act.' This provision clearly sets out the parameters under which the international responsibility of an international organisation may be invoked. DARIO is not

23 UNGA, Responsibility of international organisations: Texts and titles of draft articles 1 to 67 adopted by the Drafting Committee on second reading in 2011, UN A/CN.4/L.778 (30 May 2011).

24 Condorelli L and Kress C, 'The rules of attribution: General considerations' in Crawford J, Pellet A, Olleson S (eds), The law of international responsibility, Oxford University Press, Oxford, 2010, 110-145.

25 ILC, Draft articles on responsibility of states for internationally wrongful acts..

26 ILC, Draft articles on responsibility of states for internationally wrongful acts, Article 8. Note that DARIO follows the similar approach to ASR in terms of the 'breach' and 'attribution' (see Articles 6-9). It must be noted though that this concept of 'effective control' versus 'overall control' has been the subject of international litigation before the ICJ and the ICTY. See Cassese A, 'The Nicaragua and Tadić tests revisited in light of the ICJ judgment on genocide in Bosnia', 18(4) European Journal of International Law,2007, 649-668.

27 UNGA, Doc. A/66/10. 
concerned with issues of liability or responsibility incurred under municipal law; it only takes the perspective of international law into consideration. ${ }^{28}$ Notably, the international responsibility of an international organisation may be engaged if it takes active part in assisting or aiding another organisation or a state in the commission of an internationally wrongful act. Similarly, if an international organisation controls, directs or coerces another entity (be it a state or an organisation) into committing a wrongful act, then it will be held responsible under international law.

Article 3 of DARIO provides that; 'Every internationally wrongful act of an international organisation entails the international responsibility of that organisation'. The wording of the provision is almost identical to Article 1 of the ASR. ${ }^{29}$ Therefore, when an international organisation breaches its obligation or commits an internationally wrongful act under international law, its responsibility is 'entailed'. The ICJ, in the advisory opinion on Difference relating to immunity from legal process of a Special Rapporteur of the Commission on Human Rights, posited that:

[t] he Court wishes to point out that the question of immunity from legal process is distinct from the issue of compensation for any damages incurred as a result of acts performed by the United Nations or by its agents acting in their official capacity.....The United Nations may be required to bear responsibility for the damage arising from such acts. ${ }^{30}$

The responsibility of international organisations within the meaning of the 'effective control' standard is enshrined in Articles 6 and 7 of the DARIO. ${ }^{31}$ This means that an international organisation has control over specific acts or

\footnotetext{
Para 3 of the ILC commentary on Article 1, DARIO.

29 This is so because "the principle of state responsibility—widely accepted to be applicable to international organisations - that damage caused in breach of an international obligation and which is attributable to the state (or to the organisation) entails the international responsibility of the state (or of the organization) [...]"

30 ICJ Reports 1999, 88-89, para 66.

31 "The Commentary to the DARIO distinguishes between state organs which are fully seconded to an international organization and state organs which to a certain extent still continue to act as organs of their home state during their secondment. Whereas according to the Commentary the conduct of fully seconded organs is attributable only to the receiving organization and therefore falls under the general rule of attribution set out in Article 6 DARIO, the conduct of not fully seconded organs, such as military contingents placed at the disposal of the United Nations for the purposes of a peace-keeping operation, is to be attributed either to the seconding state or to the receiving organization on the basis of the effective control test." See also Sari A, 'UN peacekeeping operations and Article 7 ARIO: The missing link' International Organizations Law Review 9(1) 2012, 77-85.
} 
operations. ${ }^{32}$ The concept of effective control has been controversial ${ }^{33}$ in nature due to a number of instances in which the $\mathrm{UN}$ as an international organisation was found to have 'effective control' over peace-keeping troops. ${ }^{34}$ The ILC commentary on Article 7 of DARIO ${ }^{35}$ made the notion of 'effective control' even more air-tight, in a bid to protect the UN after the initial cases finding the commission of atrocities by peace-keeping troops as being attributable to the UN. The commentary provided the notion of 'exclusive command and control' in a bid to make the threshold of attribution to international organisations 'higher'.

The Commentary to the DARIO makes it clear that the conduct of soldiers from a troop-contributing state carrying out peace-keeping missions 'must be attributed with reference to factual criteria alone. ${ }^{36}$ This concept is best explained by the Al Jedda case which concerned the attribution of measures of internment in Iraq to the UN or to the armed forces of the UK. The European Court of Human Rights (ECHR) resolved the issue by determining that the acts of the British forces in Iraq were to be attributable to the UK, not to the UN. This was because the American and British missions in Iraq had already been there before the UN had become involved. Also, the UN resolutions on Iraq appeared to recognise that it was not the UN that was (legally speaking) acting on the ground in Iraq. Moreover, the UN had actually opposed some of the relevant measures, suggesting that those measures were not theirs. ${ }^{37}$

Havingaving analysed what is meant by the international legal responsibility and more so of the UN, it is prudent to narrow down to an analysis of the doctrine of R2P so as to determine whether the UN has a responsibility to prevent genocide.

32 Case concerning military and paramilitary activities in and against Nicaragua (Nicaragua v United States of America), Judgment (Merits), ICJ Reports 1986, para.105-115. ICTY, Appeals Chamber, Tadic, 15 July 1999 (Case no. IT-94-1-A).

33 The decision in Tadic rejected the notion of 'effective control' which had been accepted in the Case concerning military and paramilitary activities in and against Nicaragua, ICJ, para $105-115$. Take note that the ICJ Bosnia and Herzegovina v Serbia and Montenegro, reverted to its initial position as enunciated in the Nicaragua case.

34 Mothers of Srebrenica et alv State of The Netherlands and the United Nations (2012), Supreme Court of The Netherlands. Al-Jedda v. United Kingdom, ECtHR Judgment of 7 July 2011.

35 Para 9, ILC Commentary on Article 7 DARIO.

36 Sari A, 'UN peacekeeping operations and Article 7 ARIO'.

37 Al-jedda v United Kingdom, ECtHR, para 80-86. See also, UNSC, S/2007/768 (2008) Report of the Secretary-General on the United Nations Interim Administration Mission in Kosovo. 


\section{Responsibility to protect (R2P)}

The R2P doctrine is one that is grounded on collective security and human rights protection. However, while it is always said that R2P has attained the status of an international norm, it has not yet reached the position of such universality. ${ }^{38}$

Nevertheless, this doctrine is grounded on the notion of sovereignty of states in that sovereignty is not a privilege, but a responsibility. At the very minimum, every state must protect its population from genocide, war crimes, ethnic cleaning and crimes against humanity. In the case of a state failing to ensure such protection, this responsibility must be borne by the international community. R2P, as it is commonly known, was universally endorsed at the 2005 World Sum$\mathrm{mit}^{39}$ and then re-affirmed in 2006 by the $\mathrm{UN} .{ }^{40}$ Hence, this is a responsibility that is an obligation to states first, and then to the international community. ${ }^{41}$

The idea of sovereignty is grounded on the aspect that there is no higher authority from outside the state. This places great power within the state in the management of its affairs in relation to its population, resources and territory. But with power comes great responsibility; consequently, states have the responsibility to protect populations from atrocities as an inherent part of state sovereignty. ${ }^{42}$

\section{States responsibility to protect}

State responsibility to protect envisages the notion that each individual state has the responsibility to protect its populations from genocide, war crimes, ethnic cleansing and crimes against humanity as an important aspect of its sovereignty. This entails the prevention of such crimes, including their incitement, through

38 Quinton-Brown P, 'Mapping dissent: The responsibility to protect and its state critics,' 5(3) Global Responsibility to Protect, 2013, 282.

39 UNGA, 2005 World Summit Outcome, UN A/RES/60/1 (24 October 2005).

40 In April 2006, the UN Security Council formalised their support of the R2P by reaffirming the provisions of the paragraphs from the 2005 World Summit Outcome. See, UNSC S/RES/1674 (2006), para 4. Finally, the UN Secretary General, Ban Ki-moon, released a report the same year, Implementing the Responsibility to Protect, which argued for the implementation for R2P. Its arguments were subsequently discussed at the 2009 UN General Assembly resulting in Resolution A/RES/63/308, which acknowledges the debate and Ban Ki-moon's report and proposes that the General Assembly should continue its consideration of R2P.

41 Zyberi $G$, ${ }^{\circ}$ The role of the international courts and tribunals in the pursuit of peace, justice and the responsibility to protect' in Bailliet C and Larsen KM (eds), Promoting peace through international law, Oxford University Press, Oxford, 2015.

42 UNGA, 2005 World Summit Outcome, para.138. 
appropriate and necessary means. States accept that responsibility and act in accordance with it. The international community, on the other hand, is tasked to help as appropriate, encourage and help states to exercise this responsibility and support the UN in establishing an early warning capability.

R2P initially appeared in the International Commission on Intervention and State Sovereignty (ICISS) Report. ${ }^{43}$ Its goal is to reconcile of the traditional concept of sovereignty, which involves exclusive control and supremacy over a defined territory, and the more modern notion that the sovereignty of a state includes the primary responsibility to protect its own people. ${ }^{44}$

This notion of sovereignty has, by and large, been adopted by the international community, and is now enshrined in the so-called 'three pillars' of R2P. These are: ${ }^{45}$ The protection responsibilities of the state (Pillar 1), international assistance and capacity-building (Pillar 2), and timely and decisive response (Pil$\operatorname{lar} 3)$.

Very little has been said about R2P in the international courts regime due to the legal uncertainty of this principle. Because of the limited nature of this article, it does not analyse the existing literature on R2P. This notwithstanding, the meaning of R2P is generally set out in UN documents. This principle has been criticised to be a legal and political concept rather than solely a legal one. ${ }^{46}$ International law publicists have argued that the R2P has no legal basis and its effect was just to cement a legal regime that was already there. ${ }^{47}$ It can only supplement existing frameworks such as the Rome Statute and the UN Security Council (UNSC) interventions. ${ }^{48}$

43 International Commission on Intervention and State Sovereignty (ICISS), The responsibility to protect, International Development Research Centre, Ottawa, 2001.

44 Kersten M, 'Gaza and Israel - A case for international humanitarian law, not R2P' Justice in Conflict, 24 July 2014, -<http://justiceinconflict.org/2014/07/24/gaza-and-israel-a-case-for-internationalhumanitarian-law-not-r2p/> accessed on 12 March 2020.

45 Stipulated in UNGA, 2005 World Summit Outcome, para 138-140. Formulated in UNGA, Implementing the responsibility to protect, UN A/63/677 (12 January 2009).

46 Serrano M, 'The responsibility to protect and its critics: Explaining the consensus' 3 Global Responsibility to Protect 3, 2011, 1-2.

47 Crawford T and Kuperman A (eds) Gambling on bumanitarian intervention: moral bazard,rebellion and civil war, Routledge, New York, 2006.

48 The Security Council can diplomatically engage the parties concerned under Chapter VI of the United Nations Charter to ensure the protection of populations suffering from mass atrocity crimes. The Security Council may also take non-coercive action under Chapter VI to encourage states to exercise their responsibility to protect their population from mass atrocities. See Articles 33, 34, 36, 38, 39, 41 and 42, UN Charter. 


\section{UN responsibility to protect}

The international community, through the $\mathrm{UN}$, also has the responsibility to use appropriate diplomatic, humanitarian and other peaceful means, to help protect populations from genocide, war crimes, ethnic cleansing and crimes against humanity. ${ }^{49}$ In this context, the organised international community should prepare to take collective action, through the UNSC, in a timely and decisive manner ${ }^{50}$ on a case-by-case basis and in cooperation with relevant regional organisations, as appropriate, should peaceful means be inadequate and where national authorities fail to protect their populations. ${ }^{51}$ It must be noted, however, that the responsibility given to the $\mathrm{UN}$ in relation to R2P under the World Summit Outcome Document is not one that passively 'guarantees' that the UN shall act;it provides that the UN also has the responsibility to act.

\section{'Failure to prevent'}

The ICISS report provides that 'prevention is the single most important dimension of the responsibility to protect ${ }^{52}$ stating that 'it is high time for the international community to be doing more to close the gap between rhetorical support for prevention and tangible commitment. ${ }^{53}$ Importantly, R2P provides for a much larger set of policy tools to forestall the need for humanitarian intervention in recognition that prevention is the best form of protection. ${ }^{54}$ But what if the opposite happens? What does international law consider as a 'failure to prevent?

\section{A conventional definitional approach}

The closest relation to the aspect of 'failure to prevent' can be traced to one of the rules of customary international humanitarian law ${ }^{55}$ that commanders and other superiors are criminally responsible for war crimes committed by their subordinates if they knew, or had reason to know, that the subordinates were about to commit or were committing such crimes and did not take all necessary

\footnotetext{
UNGA, World Summit Outcome, para 139.

UNGA, World Summit Outcome, para 139. See also, Chapter VI and VII, UN Charter.

UNGA, World Summit Outcome, para 139.

ICISS, The responsibility to protect, 2001, XI. See also Rosenburg S, 'Responsibility to protect: A framework for prevention’ 1 Global Responsibility to Protect, 2009.

ICISS, The responsibility to protect, 2001, 19.

UNGA, Implementing the responsibility to protect.

5 Rule 153, Customary International Humanitarian Law, 2005, Volume I: Rules.
} 
and reasonable measures in their power to prevent their commission, or if such crimes had been committed, to punish the persons responsible..$^{56}$ This rule is also included in the 1977 Additional Protocol I to the Geneva Convention ${ }^{57}$ as well as recognised in principle by the Rome Statute 58 and the Statute of the International Criminal Tribunal for the former Yugoslavia. ${ }^{59}$

\section{A judicial definitional approach}

According to case law, the 'obligation to prevent' has been upheld. ${ }^{60}$ However, the commander's responsibility also applies to civilians who are liable for failing to prevent jus cogens crimes. It has also been held that this responsibility is not limited to situations where the superior has actual knowledge of the crimes committed or about to be committed by his or her subordinates, but that constructive knowledge is sufficient. This is expressed in various sources as: 'had reason to know.' This establishes several meanings according to what is allowed by the courts: (1) had information which 'should have enabled (the commander/ superior) to conclude, in the circumstances at the time', ${ }^{11}(2)$ the commander/ superior, 'owing to the circumstances at the time, should have known',62 (3) the commander/superior was 'at fault in having failed to acquire such knowledge', ${ }^{63}$ and (4) the commander/superior was 'criminally negligent in failing to know. ${ }^{364}$ These formulations cover the concept of constructive knowledge essentially.

Similarly, in light of the conventional and judicial definition of 'failure to prevent', the same can be transposed onto states and the international community. The aspects of 'knowledge of atrocities taking place or about to take place' and 'not taking all necessary and reasonable measures in their power to prevent their commission' are important in defining 'failure to prevent.'

\footnotetext{
56 See, Von Leeb (The High Command Trial) case, United States, Military Tribunal at Nuremberg.

57 See, Article 87 (3), Protocol Additional to the Geneva Conventions of 12 August 1949 and relating to the Protection of Victims of International Armed Conflicts, 1125 UNTS 3.

58 Article 28, Rome Statutes for the International Criminal Court, adopted by way of United Nations Diplomatic Conference of Plenipotentiaries on the Establishment of an International Criminal Court, on 17 July 1998, (2187 UNTS 90).

59 Article 7(3), Statute of the International Criminal Tribunal for the Former Yugoslavia (as amended on 17 May 2002).

${ }_{60}$ Bosnia and Herzegovina v Serbia and Montenegro, ICJ.

61 Article 87 (3), Protocol Additional to the Geneva Conventions of 12 August 1949 and relating to the Protection of Victims of International Armed Conflicts.

62 Article 28, Protocol Additional to the Geneva Conventions of 12 August 1949 and relating to the Protection of Victims of International Armed Conflicts.

63. Case of the Major War Criminals, International Military Tribunal (Tokyo).

${ }^{64}$ Crimes against Humanity and War Crimes Act, S.C. 2000, c. 24,Canada.
} 
The determination of the failure to prevent lies in the knowledge and in the failure to take all necessary measures to prevent the commission of the atrocities. Importantly, the obligation to prevent and the failure to prevent are a question of conduct and not one of result. ${ }^{65}$ Hence, the state or international community is not mandated to succeed in, for instance, preventing genocide. ${ }^{66}$ Rather, the obligation is to ensure that all necessary means have been employed to prevent the continuance of the atrocities. Therefore, in order to conclude the actuality of a 'failure to prevent,' a state or the international community should have failed to exercise their due diligence by taking all necessary measures that are within their power to prevent the escalation or the committing of atrocities. ${ }^{67}$

\section{Obligation to prevent genocide: A rule under customary international law?}

\section{General}

Article 38(1) of the ICJ Statute recognises treaties, CIL, general principles, judicial decisions, and teachings of the most highly qualified publicists as the most authoritative sources of international law. ${ }^{68}$ Although this was intended to apply to the ICJ proceedings, it has become the most acknowledged and widely quoted sources of international law. ${ }^{69}$ Article 38(1)(b) provides that, '[t] he Court, whose function is to decide in accordance with international law such disputes as are submitted to it, shall apply international custom, as evidence of a general practice accepted as law.'

Crucially, the traditional doctrine of CIL calls for two general requirements before a customary rule comes into existence. First, there is an objective element known as state practice, and, second, a subjective element called opinio juris, which in other words describes the physical element and the belief that states exercise this practice out of a legal obligation. States cannot derogate from some of these rules because they are so important, for example, jus cogens norms. The

\footnotetext{
65 Zyberi G, 'The role of the international courts and tribunals in the pursuit of peace, justice and the responsibility to protect'.

Zyberi G, 'The role of the international courts and tribunals in the pursuit of peace'.

${ }_{67}$ Zyberi G, 'The role of the international courts and tribunals in the pursuit of peace'. See also, Bosnia and Herzegovina $v$ Serbia and Montenegro, ICJ, para 430.

68 Dixon $\mathrm{M}$ and McCorquodale R, Cases and materials on international law, 4ed, Oxford University Press, Oxford, 2003, 24, 54.

69 Dixon $\mathrm{M}$ and McCorquodale R, Cases and materials on international law, 24,54.
} 
ICJ in the North Sea Continental Shelf case ${ }^{70}$ explained how these two elements operate in the creation of a new custom. The position taken by the ICJ in this case clearly reflects the traditional understanding of CIL, wherein state practice was the essential ingredient in the formation of CIL, together with opinio juris. Without these two indispensable elements, the rule of CIL cannot be claimed as legally existing and binding upon states. ${ }^{71}$ The question then is; what is the status and scope of CIL in today's legal order?

\section{The status and scope of CIL in the international legal order}

Until recently, the rules of general international law were all customary rules. ${ }^{72}$ Most of these still exist, although modified and adapted to the changes in the international relations. Rules of CIL evolved after a long historical process culminating with their recognition by the international community. For a custom to give rise to a binding rule, it must have been practiced and accepted as obligatory by the international community. ${ }^{73}$

The binding elements of CIL are deduced from:

1. Duration - Proof of consistency and generality of the practice is necessary ${ }^{74}$

2. Uniformity and generality - State practice must be uniform, consistent and general and must be coupled with a belief that the practice is obligatory rather than habitual ${ }^{75}$

3. Opinio juris sive necessitatis - The rule in question must be regarded by the states as binding in law in that they are under a legal obligation to follow that rule ${ }^{76}$

Therefore, unlike treaties (which are applicable only to contracting parties), CIL applies to all states.

In this regard, would the obligation to prevent genocide be a CIL norm? The answer to this is not as straight forward as 'yes' or 'no'. Most importantly,

70 North Sea Continental Shelf Cases (Federal Republic of Germany/Denmark; Federal Republic of Germany/ Netherlands), Judgment, ICJ Reports 1969, para 77.

71 Damrosch L, Henkin L, Murphy S and Smit H, International law, cases and materials, 5ed, American Casebook Series, 2009, 60. See also Blutman L, 'Consent and customary international law' EJIL: Talk! 4 August $2014-<$ http://www.ejiltalk.org/consent-and-customary-international-law/ > accessed on 13 March 2020.

72 Tunkin G, 'Is general international law customary law only?' 4 European Journal of International Law, 1993, 534-535.

3 Cassese A, International law, 2ed, Oxford University Press, Oxford, 2005, 56.

74 North Sea Continental Shelf Cases, ICJ, 3, para 74.

75 Asylum case (Colombia v Peru), Judgment, ICJ Reports 1950, 395, para 276-7.

76 SS Lotus case (France v Turkey), Judgment, PCIJ 1927 (serie A No 10), para 28. 
customary law can co-exist with treaty law as the ICJ stated in the Nicaragua case. ${ }^{77}$ The prevention of genocide could also be of the same nature, but the courts have not pronounced the same. ${ }^{78}$

The exact status of the obligation to prevent genocide in international law is uncertain. The ECtHR simply indicated that just as the obligation not to commit genocide is a rule of jus cogens, the obligation to prevent genocide is also a norm of jus cogens. ${ }^{79}$

The ICJ has recognised the treaty obligation to prevent genocide ${ }^{80}$ in the Genocide Convention case. ${ }^{81}$ However, in doing so, 'the ICJ was very careful in limiting its holding to the confines of the Genocide Convention only explicitly refusing to step outside its boundaries more so in relation to the character of the obligation to prevent genocide in international law. ${ }^{\text {' } 22}$ Notably, the UN is not a party to the Genocide Convention (and indeed cannot be as it is only open to states as per Article XI). It, therefore, cannot be bound to the duty to prevent genocide. ${ }^{83}$

\section{Concept, principle or norm?}

Genocide has often been pronounced as the 'crime of crimes', ${ }^{84}$ and, according to the ICJ, the crime of genocide can give rise to individual and state responsibility even when a state has not ratified the Genocide Convention. In the fore-mentioned Genocide Convention Case, the ICJ held that, "the principles underlying the Convention are principles which are recognized by civilised nations as

Case concerning military and paramilitary activities in and against Nicaragua, ICJ, 14, para 73.

78 See Mothers of Srebrenica et al v State of The Netherlands and the United Nations (2012), Supreme Court of The Netherlands. See also, Stichting Mothers of Srebrenica and others against the Netherlands, ECtHR Judgment of 11 June 2013.

79 Stichting Mothers of Srebrenica, ECtHR, para 157.

80 Article 1, Genocide Convention.

81 Bosnia-Herzegovina $v$ Yugoslavia, ICJ, 595, para 429. See also Ventura M \& Akande D, 'Mothers of Srebrenica: The obligation to prevent genocide and jus cogens - Implications for humanitarian intervention', EJIL: Talk! 6 September 2013 -<http://www.ejiltalk.org/ignoring-the-elephant-inthe-room-in-mothers-of-srebrenica-is-the-obligation-to-prevent-genocide-jus-cogens / > accessed 13 March 2020.

82 Ventura M\&Akande D, 'Mothers of Srebrenica'-<http://www.ejiltalk.org/ignoring-the-elephant-inthe-room-in-mothers-of-srebrenica-is-the-obligation-to-prevent-genocide-jus-cogens / > accessed 13 March 2020.

83 Ventura M\&Akande D, 'Mothers of Srebrenica' -<http://www.ejiltalk.org/ignoring-the-elephant-inthe-room-in-mothers-of-srebrenica-is-the-obligation-to-prevent-genocide-jus-cogens $/>$ accessed 13 March 2020.

84 Prosecutor $v$ Kambanda, Judgment, ICTR 2000 (97-23-A), para 16. 
binding on states without any conventional obligation. ${ }^{95}$ Clearly, this statement establishes the prohibition of genocide as a general principle of international law, and is, therefore, legally binding upon all states as a principle of international law.

Moreover, the prohibition of genocide remains a jus cogens norm as discussed, and has, therefore, peremptory status under international law. This status is confirmed by the classification of genocide as one of 'the most serious crimes of concern to the international community as a whole'. ${ }^{86}$ Such grave crimes 'threaten the peace, security and well-being of the world'. ${ }^{87}$ Furthermore, the status of genocide as a peremptory norm under international law has been confirmed multiple times by numerous international scholars, and also in the jurisprudence of the ICJ ${ }^{88}$ and domestic courts alike. ${ }^{89}$ What this means is that in the hierarchy of crimes, the crime of genocide remains on top, and so the duty to prevent and punish genocide is aimed 'towards all' states due to its gravity as an erga omnes per se obligation. ${ }^{90}$ The concept of erga omnes per se obligations refers to specifically determined obligations of which states have a legal interest in protecting towards the international community as a whole. ${ }^{11}$

However, while it is clear that the obligation to prevent genocide remains an international principle, not much clarity exists as to what the obligation actually entails. As indicated before, the Genocide Convention itself does not define what is meant by "prevention." Yet, according to the ICJ, any state which is in the position to influence 'effectively the action of persons likely to commit, or already committing genocide ${ }^{93}$ is under the obligation to 'take all necessary measures to prevent genocide which were within its powers. ${ }^{94}$

85 Bosnia-Herzegovina v Yugoslavia, ICJ, para 23.

86 Article 5, Rome Statute of the International Criminal Court (2002).

87 Preamble, Rome Statute.

88 For instance in the Armed Activities on the Territory of the Congo (New Application: 2002) (Democratic Republic. Congo v Rwanda), Jurisdiction and Admissibility, ICJ Reports 2006, para 64 and 125.

89 Schabas W, Genocide in international law, Cambridge University Press, Cambridge, 2000, 4-5. See also Knorr M, 'The international crime of genocide: Obligations jus cogens and erga omnes, and their impact on universal jurisdiction' 32 European Human Rights Report, 2011, 34-35.

90 Barcelona Traction, Light and Power Company, Limited (Belgium v Spain) (1962-1970) Second Phase, Judgment, ICJ Reports 1970, para 33-34.

91 Barcelona Traction, ICJ, para 33-34.

92 Article 3, Genocide Convention.

93 Bosnia and Herzegovina v Serbia and Montenegro, ICJ, para 430.

94 Bosnia and Herzegovina v Serbia and Montenegro, ICJ, para 430. 


\section{Relationship with international legal responsibility}

It has already been established that the UN possesses international legal personality, and thus, international legal responsibility. With regards to the subject matter, it is therefore relevant to ask the question: is the obligation to prevent genocide only binding upon states, or does it generate binding obligations on international entities, such as the UN, as well?

Since the UN is not a party to the Genocide Convention, it could be argued that it is not bound by any obligation the Convention creates. ${ }^{95}$ Yet, it can also be argued that, by virtue of the status of genocide under CIL, as a peremptory norm, as well as the fact that the duty to prevent genocide is imposed on all states under Article 1 of the Convention, this duty is extended to the UN as the main entity in today's inter-state society. ${ }^{96}$ Furthermore, without enforcement by the UN, the prohibition of genocide itself would arguably lose its meaning and be continuously violated. As a result, the Genocide Convention should be understood as not only creating rights, but also obligations for international organisations, as well as for states. ${ }^{97}$ Importantly, however, this is due to the customary rules contained in the Convention since it technically only binds states, not the UN.

To support this claim, legal scholars, such as Andre de Hoogh, have argued that, "the UN is bound by the rules of universal customary law. ${ }^{\text {, }}$ Also, the ICJ confirmed this in its interpretation on the Agreement between the World Health Organisation (WHO) and Egypt, where the Court held that, "[i]nternational organisations are subjects of international law and, as such, are bound by any obligations incumbent upon them under general rules of international law, under their constitutions or under international agreements to which they are parties. ${ }^{39}$

Consequently, it can be deduced that the obligation to prevent genocide is not only a binding duty bestowed upon states, but also the UN. However, this is an assertion that has not been pronounced by any court or through any related legal means. It is instead a deduction of the legal obligations that exist towards states, linked to the fact that states are what constitute international organisations such as the UN.

\footnotetext{
95 Ruvebana E, Prevention of genocide under international law, 261.

96 Ruvebana E, Prevention of genocide under international law, 261.

97 Ruvebana E, Prevention of genocide under international law, 261.

98 De Hoogh A, Obligations erga omnes and international crimes: A theoretical inquiry into the implementation and enforcement of the international responsibility of states, Kluwer Law International, The Hague/London/ Boston, 1996, 104.

99 Interpretation of the agreement of 25 March 1951 between the WHO and Egypt, ICJ, 73, para 37.
} 


\section{Relationship with responsibility to protect $(R 2 P)$}

So why is the doctrine of R2P relevant in this regard? To begin with, the prevention of mass atrocities (such as genocide) forms an integral part of the doctrine of R2P. After all, the best way to ensure that populations are protected is to prevent mass atrocities from occurring in the first place. ${ }^{100}$ According to ICISS, 'prevention is the single most important dimension of responsibility to protect'101. Thus, as opposed to what many believe, R2P is much more than just another name for humanitarian intervention. The doctrine takes a much broader view, which allows for humanitarian intervention only as a last resort. ${ }^{102}$

However, as illustrated earlier, R2P remains a vague and highly debated concept whose implications and consequences are in need of assessment. In this regard, commentators have argued that the ICJ missed an opportunity to elaborate on the scope and existence of R2P in the Bosnia v Serbia case, which was a ruling on the breach of the obligation to prevent. ${ }^{103}$ Nevertheless, the core of the concept remains straightforward. According to Andrea Gattini:

[A]s a corollary to its sovereignty, every state has not only the right but also the duty towards its own population to protect it as far as possible from grave attacks on its survival, whether their cause be natural or human. If the state is unable or unwilling to cope with its primary responsibility, then it is the turn of the international community to give voice to its concern and to rise to its subsidiary responsibility, primarily through the collective system of the United Nations, but possibly also, and especially so in the case of deadlock in the UN decision process, outside the system through multilateral or even unilateral initiatives. ${ }^{104}$

Hence, the relationship between the obligation to prevent and R2P is obvious in that the responsibility to protect can be read as a state's obligation to protect its own population and soprevent atrocities such as genocide.

\footnotetext{
100 Rosenberg S, 'Responsibility to protect: A framework for prevention' 1 Global Responsibility to Protect, $2009,442$.

101 ICISS, The responsibility to protect, 2001, 6.

102 De Hoogh A, Obligations erga omnes and international crimes, 443.

103 Gattini A, 'Breach of the obligation to prevent and reparation thereof in the ICJ's Genocide Judgement' European Journal of International Law, 2007, 698.

104 Gattini A, 'Breach of the obligation to prevent and reparation,' 698.
} 


\section{Is the UN bound by the obligation to prevent genocide?}

\section{General}

Having defined and discussed the various aspects of the obligation to prevent genocide, the key question for determination is, since the UN is bound by the obligation to prevent genocide, what procedures are available to hold the UN responsible for such failures? These critical issues are discussed in this section.

\section{Is the UN bound by CIL?}

The UN is not a party to any international humanitarian law treaties, ${ }^{105}$ but there is support in literature for the view that it is bound by CIL. ${ }^{106}$ These international human rights standards, including international customary law, bind both members and non-members of the UN. ${ }^{107}$ It is highly unlikely that the member states could delegate to the UN a power to violate international customary law. ${ }^{108}$ This is also recognised in the preamble and Articles 1(3) and 55 of the UN Charter. ${ }^{109}$ The preamble reads:

[W] the peoples of the United Nations determined to reaffirm faith in fundamental human rights, in the dignity and worth of the human person, in the equal rights of men and women and of nations large and small, and to establish conditions under which justice and respect for the obligations arising from treaties and other sources of international law can be maintained.

From the above preamble, member states had a common understanding when forming the UN in 1945 that international organisations would respect the rule of law and international customary law. Based on this premise, the UN is bound by CIL.

\footnotetext{
105 Quenivet N, 'Binding the United Nations to human rights norms by way of the laws of treaties' 42 George Washington International Law Review, 592. See also Zwanenburg M, 'United Nations and international humanitarian law' Max Planck. Encyclopedia of Public International Law, 2013 - <http://opil. ouplaw.com/view/10.1093/law:epil/9780199231690/law-9780199231690-e1675>- accessed on 13 March 2020.

106 See Zwanenburg M, 'United Nations and international humanitarian law'.

107 Charney JI, 'Universal international law' 87 (4) American Journal of International Law, 1993.

108 Crush J, 'The Responsibility to Protect in International Law' E-International Relations Students, 31 May 2013, - < http:/ /www.e-ir.info/2013/05/31/the-responsibility-to-protect-in-international-law/ $>$ - accessed 13 March 2020.

109 Preamble, Charter of the United Nations, 24 October 1945, 1 UNTS XVI.
} 


\section{Select instances in which the UN has been deemed to have failed to prevent genocide}

Having assessed the nature of the obligation to prevent genocide, it is prudent to assess the failures of the UN to prevent genocide. This will be looked at chronologically over the years.

\section{Bosnia-Herzegovina}

The fall of Srebrenica became a further damaging symbol of the UN's failure at peace-keeping in a new era of civil wars, and it demonstrated the inadequacy of a system that allowed political considerations to colour military decisions when troops were under the command of the UN. ${ }^{110}$ But at the heart of the problem of protecting the safe areas - Bihac, Goradze, Sarajevo, Srebrenica, Tuzla, and Zepa - was the refusal of the UNSC members, including the United States, to authorise enough troops to do the job. Boutros Ghali wanted 34,000; the UNSC authorised only 7,400. ${ }^{111}$

In the genocidal situation, Bosnian Serb forces advanced on Srebrenica, overwhelming a battalion of Dutch peace-keeping forces stationed there. Serbian forces subsequently separated the Bosniak civilians at Srebrenica, putting the women and girls on buses and sending them to Bosnian-held territory. Some of the women were raped or sexually assaulted, while the men and boys who remained behind were killed immediately or moved to mass killing sites. Estimates of Bosniaks killed by Serb forces at Srebrenica range from around 7,000 to more than $8,000 .{ }^{112}$ Though the international community did little to prevent the systematic atrocities committed against Bosniaks and Croats in Bosnia while they were occurring, it did actively seek justice against those who committed them. In May 1993, the UNSC created the International Criminal Tribunal for the former

110 'Bosnian Genocide' History, 30 October 2019-<http://www.history.com/topics/bosnian-genocide>- accessed on 13 March 2020. The United Nations Protection Force (UNPROFOR) was created by UN Security Council Resolution 743 on 21 February 1992. Its mandate for Bosnia and Herzegovina was to keep the population alive while the war ended.

111 See UNGA, Report of the Secretary General pursuant to General Assembly Resolution 53/35: The fall of Srebrenica, UN A/54/ 549 (15 November 1999). See also Crossette B, 'UN details its failure to stop '95 Bosnian Massacre’ New York Times, 16 November 1999 -<http:/ /www.nytimes.com/1999/11/16/ world/un-details-its-failure-to-stop-95-bosnia-massacre.html> accessed on 13 March 2020.

112 'Bosnian Genocide,' < http://www.history.com/topics/bosnian-genocide> accessed on 13 March 2020. 
Yugoslavia (ICTY) at The Hague, Netherlands. ${ }^{113}$ Recently, General Mladic was found guilty of committing crimes against humanity in the ICTY. ${ }^{114}$

\section{Rwanda}

Former UN Secretary General Koffi Annan acknowledged the systematic failure of the UN in relation to the Rwandan Genocide and expressed his 'deep remorse' on behalf of the organisation. ${ }^{115}$ Annan, who was the head of the UN peace-keeping operations during the genocide, commissioned a report to find out the truth about the UN role in the massacre and to learn from the mistakes. The UN launched its peace-keeping mission for Rwanda to monitor a cease-fire agreement between the Rwandan Hutu Government and the rebel Rwandese Patriotic Front. ${ }^{116}$ The mission was not allowed to use military force to achieve its aims; it was limited to investigating breaches in the cease-fire, helping humanitarian aid deliveries and contributing to the security of the capital, Kigali. This mission proved insufficient after the Government launched the slaughter of an estimated 800,000 minority Tutsis and moderate Hutus following the attack on the Rwandan President's plane on 6 April 1994. This insufficiency has been a clarion call for the assessment of the UN's failure to prevent genocide, as echoed by the former UN Secretary General Ban Ki Moon, since this has left the UN ashamed of its failures. ${ }^{117}$

113 The UN Security Council passed Resolution 827 formally establishing the International Criminal Tribunal for the former Yugoslavia, known as the ICTY. This resolution contained the Statute of the ICTY, which determined the tribunal's jurisdiction and organisational structure, as well as the criminal procedure in general terms.

114 Prosecutor v. Mladic, ICTY, IT-09-92.

115 Human Rights Watch, Leave none to tell the story: Genocide in Rwanda, March 1999-< https://www.hrw. org/reports/1999/rwanda/ > accessed on 13 March 2020.

116 In October 1993, the Security Council, by its Resolution 872 (1993), established the United Nations Assistance Mission for Rwanda (UNAMIR), to help the parties implement the agreement, monitor its implementation and support the transitional Government.

117 Ki-moon B, 'Remarks at the commemoration of the 20th anniversary of the Rwandan Genocide' Kigali, 7 April 2014 -<https://www.un.org/sg/en/content/sg/speeches/2014-04-07/remarkscommemoration-20th-anniversary-rwandan-genocide>- accessed on 13 March 2020. It must be noted that the UNSC through S/RES/955 (1994) established the ICTR to 'prosecute persons responsible for genocide and other serious violations of international humanitarian law committed in the territory of Rwanda and neighbouring states between 1 January 1994 and 31 December 1994.' It was formally closed in 2015 after concluding its duty. 


\section{Darfur}

The UN failed to protect civilians in the war-torn western region of Sudan. In 2003, two Darfur rebel movements - the Sudan Liberation Army (SLA) and the Justice and Equality Movement (JEM) - took up arms against the Sudanese Government, complaining about the marginalisation of the area and the failure to protect sedentary people from attacks by nomads. ${ }^{118}$ The Government of Sudan supposedly responded by unleashing Arab militias, known as Janjaweed or 'devils on horseback.' Sudanese forces and the Janjaweed militia attacked hundreds of villages throughout Darfur. Over 400 villages were completely destroyed and millions of civilians were forced to flee their homes. ${ }^{119}$ African farmers and others in Darfur were systematically displaced and murdered at the hands of the Janjaweed. The genocide in Darfur has so far claimed 400,000 lives and displaced over 2,500,000 people. By 2016, more than 100 people died each day; 5000 every month. ${ }^{120}$ The Sudanese Government disputes these estimates and denies any connection with the Janjaweed. This situation is further compounded by the fact that there was an incident of mass rape of over 200 women and girls by the Sudanese Armed Forces (SAF) in Tabit. ${ }^{121}$

United Nations-African Union Mission in Darfur (UNAMID) ${ }^{122}$ negotiated permission from the Sudanese authorities to investigate Tabit. Thereafter, it declared that it found no evidence of such crimes and that villagers 'coexist peacefully' with the army. This was astounding as it was far from the truth, at

118 Adam A 'Darfur: Betrayed by the UN' World Policy Institute, 18 December 2014-< https://webcache. googleusercontent.com/search?q=cache:-oM4rqGhsLYJ:https://worldpolicy.org/2014/12/18/ darfur-betrayed-by-the-un/ $\& \mathrm{~cd}=1 \& \mathrm{kl}=$ en\&ct=clnk\&gl=ke>- accessed on 13 March 2020.

119 Edwards A, 'Suspected Sudanese war criminal 'who shot so many people he lost count' lives unsupervised and on benefits in Britain' Daily Mail, 13 March 2013 -<https://www.dailymail.co.uk/ news/article-2292673/Suspected-Sudanese-war-criminal-shot-people-lost-count-lives-unsupervised-benefits-Britain.html> accessed on 13 March 2020.

120 Edwards A, 'Suspected Sudanese war criminal,' -<https://www.dailymail.co.uk/news/article-2292673/Suspected-Sudanese-war-criminal-shot-people-lost-count-lives-unsupervised-benefitsBritain.html> accessed on 13 March 2020.

121 'Mission in trouble, leaks and whistle-blowing expose the UN mission in Darfur' Economist, 4 December 2018, available at, <http://www.economist.com/news/middle-east-and-africa/21635613leaks-and-whistle-blowing-expose-un-mission-darfur-mission-trouble $>$ accessed on 13 March 2020.

122 Acting under Chapter VII of the Charter of the United Nations, the Security Council, by its Resolution 1769 of 31 July 2007 decided that UNAMID is authorised to take the necessary action, in the areas of deployment of its forces and as it deems within its capabilities in order to: protect its personnel, facilities, installations and equipment, and to ensure the security and freedom of movement of its own personnel and humanitarian workers; support early and effective implementation of the Darfur Peace Agreement, prevent the disruption of its implementation and armed attacks, and protect civilians, without prejudice to the responsibility of the Government of Sudan. 
least according to the 'Darfurians. ${ }^{.23}$ The incident shows how the Sudanese Government has been deliberately obstructing and manipulating the international organisation through the peace-keeping mission sanctioned by the UNSC.

However, the International Commission of Inquiry on Darfur ${ }^{124}$ strongly recommended that the UNSC refers the Darfur situation to the ICC, pursuant to Article 13(b) of the ICC Statute. This recommendation was pegged on the fact that the Commission confirmed serious violations of international human rights law and humanitarian law by all parties.

The ICC indicted the President of Sudan in 2005, and an arrest warrant was issued against him. However, no member state of the UN arrested him.. ${ }^{125} \mathrm{~A}$ decade after the genocide began, violence in Sudan continues unabated and the alleged perpetrators have not been arrested and tried. ${ }^{126}$ This situation may be pointed to the lack of an enforcement arm at the ICC; but this does not negate the point that the members of the UN have an obligation to arrest President Omar Bashir, which they have failed to do in the close to 20 countries that he has travelled to since the genocide started. ${ }^{127}$ This indicates a failure on the part of the UN first by UNAMID perpetuating atrocities instead of preventing them, and, second, through the member states of the UN failing to arrest President Bashir.

\section{Responsibility of the UN for failure to prevent genocide under international law}

\section{As Ban Ki-moon stated,}

[t] he prevention of mass atrocities demands a system-wide UN effort. Goals related to the responsibility to protect should also inform our development and peace-building work, not just our efforts in the areas of human rights, humanitarian affairs, peace-keeping and political affairs. ${ }^{128}$

23 Edwards A, 'Suspected Sudanese war criminal,' -<https://www.dailymail.co.uk/news/article-2292673/Suspected-Sudanese-war-criminal-shot-people-lost-count-lives-unsupervised-benefitsBritain.html> accessed on 13 March 2020.

124 This commission was established pursuant to United Nations Security Council Resolution 1564 (2004), adopted on 18 September 2004.

125 The Prosecutor v Omar Hassan Ahmad Al Basbir, ICC-02/05-01/09, First warrant of arrest issued by Pre-Trial Chamber I: 4 March 2009; Second warrant of arrest issued by Pre-Trial Chamber I: 12 July 2010.

126 Bashir Watch, available at <http://bashirwatch.org/> accessed on 13 March 2020.

127 Bashir Watch, < http://bashirwatch.org/> accessed on 13 March 2020.

128 Ki-moon B, 'Address to Stanley Foundation Conference on the Responsibility to Protect' Stanley Foundation Conference on Implementing the Responsibility to Protect, Tarrytown, New York, 18 January 2012. 
Article 10 of DARIO $^{129}$ states that an international organisation breaches an international obligation when it fails to meet that obligiation. The UN, as shown by the World Summit Outcome Document, has the responsibility to use appropriate diplomatic, humanitarian and other peaceful means, to help to protect populations from genocide, war crimes, ethnic cleansing and crimes against humanity. ${ }^{130}$

As stated, and on the basis of reiteration, the R2P doctrine is premised on collective security and human rights protection. This doctrine is grounded on the notion of sovereignty of states in that sovereignty is not a privilege, but a responsibility. At the very minimum,every state must protect its population from genocide, war crimes, ethnic cleaning and crimes against humanity. In the case of states failing to ensure such protection, this responsibility must be borne by the international community.

In 2007, the ICJ argued that '[to suggest] that the obligation to prevent genocide only comes into being when perpetration of genocide commences... would be absurd since the whole point of the obligation is to prevent, or attempt to prevent, the occurrence of the act. ${ }^{3131}$ It therefore determined that '[a] state's obligation to prevent, and the corresponding duty to act arise at the instant that the state learns of, or should normally have learned of, the existence of a serious risk that genocide will be committed. ${ }^{132}$

Hence, being an organised form of the international community, and pursuant to pillar 2 of the R2P doctrine, the UN is deductively tasked to step in if a state fails to protect its populations. This is through collective action to protect populations, in accordance with the UN Charter. ${ }^{133}$ In this regard, the responsibility of the UN is triggered should a state fail either by being unwilling or unable to prevent genocide. Importantly, there is no mandate to succeed in preventing genocide. ${ }^{134}$ The obligation is basically to ensure that all necessary means have been employed to prevent the continuance of atrocities. ${ }^{135}$

2011 DARIO.

130 UNGA, World Summit Outcome, para 139.

131 Bosnia-Herzegovina v Yugoslavia, ICJ, para 431. See similar argument in Scheffer D, 'Genocide and atrocity crimes' 1(3) Genocide Studies and Prevention: An International Journal, 2006, 231. See also, Mayroz E, 'The legal duty to 'prevent':After the onset of 'genocide' 14 (1) Journal of Genocide Research, $2012,83$.

132 Mayroz E, 'The legal duty to 'prevent':After the onset of 'genocide,' 83.

133 Ki-moon B, 'Address to Stanley Foundation Conference on the Responsibility to Protect'.

134 Zyberi G, 'The role of the international courts and tribunals in the pursuit of peace'.

135 Zyberi G, 'The role of the international courts and tribunals in the pursuit of peace' 


\section{Procedures that are available for holding the UN responsible for the failure to comply with international law}

Having established that the UN has an obligation to prevent genocide, what then should be the following action after failing to fulfil this obligation? It must be noted, however, that in as much as this article discusses the probability of holding the UN responsible for its failure to prevent genocide, there has just been an admission of failure by the UN. But it has never been found liable in a court of law for failure to prevent genocide.

Mediation is given as one of the procedures available to persons that wish to have the UN comply with international law. ${ }^{136}$ The UNGA has adopted a resolution that recognises the increased use of mediation, reflects on the challenges facing the international community in such mediation efforts, and calls on key actors to develop their mediation capacities. ${ }^{137}$ However, this is only implemented in private contracts with the UN and all states, but not the sphere of international customary law. 138

On the other hand, municipal and international courts have agreed that the UN has absolute immunity. ${ }^{139}$ Municipal courts have repeatedly rejected cases on the basis that the UN enjoys immunity under the Convention on the Privileges and Immunities of the United Nations, 1945. Mothers of Srebrenica is an example of such a case against the UN and the Netherlands. Both the Dutch Court and the ECHR rejected the suit against the UN. ${ }^{140}$ The Dutch Court held that the $\mathrm{UN}$ had immunity from domestic suits, even in the face of violations of jus cogens norms. The ECHR agreed ${ }^{141}$ with the Dutch rulings on the immunity of the UN. It followed the ICJ's holding in Germany v Italy. ${ }^{142}$ Although the UN has been held responsible of failure to prevent genocide principally, ${ }^{143}$ the $\mathrm{UN}$ is not bound by

36 United Nations, Handbook on the peaceful settlement of disputes between states, 1999, para 123-139.

137 'General Assembly adopts text encouraging states, organizations to bolster mediation efforts for peacefully solving disputes' - <http://www.un.org/press/en/2014/ga11537.doc.htm> accessed on 13 March 2020.

138 Article VIII, Section 29 (a), Convention on the privileges and immunities of the United Nations, 13 February 1946.

139 Georges v United Nations (2015) United States District Court, New York. Stichting Mothers of Srebrenica, ECtHR. See also Complaint, Laventure v. United Nations (2014) United States District Court (No 14CV-1611).

140 Stichting Mothers of Srebrenica, ECtHR.

141 Stichting Mothers of Srebrenica, ECtHR, para 158, 164 and 169.

142 Jurisdictional Immunities of the State (Germany v Italy :Greece intervening), Judgment, ICJ Reports 2012, 99.

143 In Nubanovic, the Dutch Supreme Court held that the same conduct could in principle be attributed both to the Netherlands and to the United Nations. In reaching this decision, the Court re- 
such judgements because ICJ decisions are only binding to state parties before it and the UN does not fall within that category. ${ }^{144}$ Notably, the Mothers of Srebrenica $^{145}$ cases involved the UN in the proceedings, but the UN effectively relied on its immunity. In the District Court decision, the court rejected the position of the Mothers that, given the immunity of the UN, the rules on attribution should be interpreted more 'broadly', as otherwise the Dutch UN peace-keepers would be placed 'above the law.'146

Further reference is made to Behrami ${ }^{147}$ where the decisive factor was whether the UNSC retained ultimate authority and control so that only operational command was delegated. While acknowledging the effectiveness or unity of the NATO command in operational matters, the Court noted that the presence of KFOR in Kosovo was based on a resolution adopted by the UNSC and concluded that KFOR was exercising lawfully delegated Chapter VII powers of the UNSC so that the impugned action was, in principle, 'attributable' to the UN. ${ }^{148}$

This decision influenced the UNSC in a 2008 Report on the United Nations Interim Administration Mission in Kosovo which provided that the international responsibility of the UN will be limited in the extent of its effective operational control. $^{149}$

The ripple effect of the UNSG Report was felt in Al-jedda $v$ United Kingdom ${ }^{150}$ where the ECHR held that the UNSC had neither effective control nor ultimate authority and control over the acts and omissions of foreign troops within the Multi-National Force and that the applicant's detention was not, therefore, attributable to the UN.

ferred to Article 48 of the ILC's Articles on the Responsibility of International Organisations (2011, DARIO). In the Mothers of Srebrenica case (para 4.34), the District Court reached the same conclusion.

46 Mothers of Srebrenica et al, para 4.35. See also, Spijkers O, 'Emerging voices: Responsibility of the Netherlands for the genocide in Srebrenica-The Nuhanović and Mothers of Srebrenica cases compared' Opinio Juris, 23 July 2014 -<http://opiniojuris.org/2014/07/23/emerging-voices-responsibility-netherlands-genocide-srebrenica-nuhanovic-mothers-srebrenica-cases-compared/ > accessed on 13 March 2020. Note that the argument of Netherlands was in reliance on Article 6 of DARIO. They argued that the peace-keepers were a UN organ. This is also the view of the UN itself. But the Court followed the ILC Commentary to DARIO, according to which a battalion of peace-keepers is not a UN organ, because the battalion to a certain extent still acts as an organ of the state supplying the soldiers. Important in this assessment is the fact that the troop-contributing state retains disciplinary powers and criminal jurisdiction over its peace-keepers (see Spijkers' article). 
In light of the cases above, it is easily identifiable that the UN has an aspect of absolute immunity when it comes to attribution of responsibility. This is a matter that has also been canvassed in the European Court of Justice in the Kadi case intricately, ${ }^{151}$ as well as in the Haitian Cholera case ${ }^{152}$ where the courts found that suits cannot be brought against the UN due to its immunity against litigation covered in various agreements.

It has been argued that the UN should not have absolute immunity, more so in relation to R2P. ${ }^{153}$ States have an obligation to take any action to withdraw any immunity in order to prevent crimes against humanity. ${ }^{154}$ However, the UN does not operate under the purview of sovereignty and established by a 'international contract' which is enforced through the UN Charter and does not serve in any jurisdiction, but rather operates in the international legal sphere. The UN does not protect any specific jurisdiction, but enforces its responsibility through its member states. This means that when the UN fails, the whole world fails deductively. ${ }^{155}$ Yet, it may be difficult to hold the UN responsible for failing to uphold the obligations to prevent genocide, as it would be an exercise in futility as seen by the judicial practice so far.

\section{Reflections and recommendation(s)}

Guglielmo Verdirame in his publication on the UN and the protection of human rights asked a pertinent question: 'Who guards the guardians?'156 This publication highlights an important problem which this article has belaboured the lack of accountability of the UN. In relation to the question of prevention of genocide that is the focus of this article, the UN has the office on Genocide Prevention and the Responsibility to Protect and a Special Advisor on the Prevention of Genocide.

\footnotetext{
151 Kadi and Al Barakaat International Foundation v Council and Commission (2008) C-402/05.

152 Georges $v$ United Nations (2015) United States District Court.

153 Reinisch A and Weber UA, 'In the shadow of Waite and Kennedy', 1 International Organizations Law Review, 2004, 61-62.

154 Cassin R, 'The Charter of Human Rights', Nobel Lecture - < http://www.nobelprize.org/nobel_ prizes/peace/laureates/1968/cassin-lecture.html > accessed on 13 March 2020.

155 Grant R and Keohane R, 'Accountability and abuses of power in world politics' American Political Science Review, 2005, 29-43.

156 Verdirame G, The UN and human rights: Who guards the guardians?, Cambridge University Press, Cambridge, 2011.
} 


\section{UN Office on Genocide Prevention and the Responsibility to Protect}

This UN Office was developed to ensure prevention and response against atrocity crimes as well as accountability of the perpetrators of atrocity crimes. This office is coupled together with that of the Special Adviser on the Prevention of Genocide, which acts as a catalyst to raise awareness of the causes and dynamics of genocide, to alert relevant actors where there is a risk of genocide, and to advocate and mobilise for appropriate action.

The turn of the $20^{\text {th }}$ century brought with it brutalities such as the Holocaust, the killing fields of Cambodia, the genocide in Rwanda and Srebrenica as well as the Darfur genocide. These events, as canvassed before, underline the failure of individual states to live up to their responsibilities and obligations under international law to protect their civilians, as well as the collective inadequacies of international institutions, more so the UN.

While this office is important, the question Guglielmo asked still lingers; 'Who guards the guardians?'. Should the UN fail to prevent genocide, what accountability mechanisms exist against it?

\section{Security Council mandate}

The UNSC has a primary responsibility under chapters VI and VII of the UN Charter ${ }^{157}$ to maintain or restore international peace and security and to ensure pacific settlement of disputes. ${ }^{158}$ This is a mandate that the UNSC succinctly captured in Resolution 242 after the six-day war between Israel and Egypt, Jordan, and Syria, where the UNSC indicated that its mandate is peace first, international law and justice second.

The UNSC as the guardian of international peace has been dogged by political debacles that have ended up derailing its main agenda such as has happened in Syria recently. ${ }^{159}$ However, the UNSC has not entirely failed in its mandate, with the Darfur situation being a case in point. The UNSC successfully referred the Sudan matter to the ICC and, as discussed herein, an arrest warrant is pending for Bashir, the former Sudanese President, for acts of genocide committed in his country.

157 Charter of the United Nations, 24 October 1945, 1 UNTS XVI.

158 Articles 33 \& 39, Charter of the United Nations.

159 See Borger J, 'UN chief calls security council's failure on Aleppo 'our generation's shame' The Guardian, 27 October 2017, https://www.theguardian.com/world/2016/oct/26/aleppo-bombings-syria-un-stephen-obrien-vitaly-churkin accessed on 13 March 2020. 
Further, pursuant to Article 24 (2) of the UN Charter, the UNSC is mandated to act on behalf of all the members of the UN and in effect on behalf of the UN. This was clearly brought out by the ICJ in the Expenses Opinion ${ }^{160}$ case where it stated that:

The responsibility conferred is "primary", not exclusive. This primary responsibility is conferred upon the Security Council, as stated in Article 24, "in order to ensure prompt and effective action". To this end, it is the Security Council which is given a power to impose an explicit obligation of compliance if for example it issues an order or command to an aggressor under Chapter VII. It is only the Security Council which can require enforcement by coercive action against an aggressor.

To this extent, the UNSC is essentially the guardian of the R2P principle. In Chapter VII of the UN Charter, the UNSC is mandated to undertake responses in a non-military ${ }^{161}$ or military ${ }^{162}$ manner against states that are a threat to international peace and security. In this regard, the UN, through the UNSC, is meant to take collective action, in a 'timely and decisive manner', to protect civilians from atrocious crimes when states 'manifestly fail' in their responsibilities.

Hence, aside from the political debates that accost any discussion that comes up in relation to the UNSC (which this article will not delve into), the UN, through the UNSC, has a mandate to prevent genocide through the means mentioned above and this is pegged on the fact that should states fail to undertake their R2P mandate, the UN could step in, albeit via consent.

\section{The UNSC and peace-keeping mandates}

Article 42 of the UN Charter allows the UNSC to undertake military measures in its quest to maintain international peace and security. The UN has undertaken this measure through peacekeeping troops.

However, as seen in the cases like the Mothers of Srebrenica, Al-Jedda, and Bosnia v Serbia - the major theme being the use of peacekeeping troops. As seen in the Srebrenica case, the challenge of holding the UN responsible for the action or inaction of the contributed peacekeeping troops, is hinged on the aspect of its immunity from litigation as the Convention on the Privileges and Immunities of the United Nations provides.

\footnotetext{
160 Certain Expenses of the United Nations (Article 17, Paragraph 2, of the Charter), Advisory Opinion, ICJ Reports 1962, 151.

161 Article 41, Charter of the United Nations.

162 Article 42, Charter of the United Nations.
} 
In order to circumvent this sort of bottleneck, the UNSC has recently adopted Resolution 2272 (2016). This resolution endorsed a new UN policy of sending entire peace-keeping units back to their contributing countries if their soldiers face repeated allegations of sex abuse. This is a step forward. However, the proposal was opposed by peace-keeping nations who argued that it amounts to collective punishment for the actions of a few individuals. Under UN rules, ${ }^{163}$ it is up to the country that contributes the peace-keepers to investigate and prosecute any soldier accused of misconduct while serving under the UN flag.

\section{Summary and conclusion}

\section{The significance of the responsibility to prevent genocide}

Prevention requires sharing responsibility and promoting collaboration between states and the international community. The duty to prevent genocide and other mass atrocities initially lies with the state, but the international community has an obligation to step in when the state fails or is unable to exercise that duty. States can no longer hide behind the concept of sovereignty to avoid foreign interference; it is a charge of responsibility where states are accountable for the welfare of their people. This principle is enshrined in Article 1 of the Genocide Convention and embodied in the principle of 'sovereignty as responsibility' and in the concept of R2P.

\section{Implementing the UN responsibility to prevent genocide under international law}

The DARIO ${ }^{164}$ provides for the responsibility of international organisations. The UN has the responsibility to use appropriate diplomatic, humanitarian and other peaceful means, to help to protect populations from genocide, war crimes, ethnic cleansing and crimes against humanity. ${ }^{165}$ The UN is required to step in where a state fails to protect its populations. This action is part of the collective action to protect populations. ${ }^{166}$ In this regard, the responsibility of the UN is triggered should a state fail either by being unwilling or unable to prevent genocide.

\footnotetext{
163 Coning C, Detzel J, Hojem P, UN Peacekeeping Operations: Principles and Guidelines Capstone Doctrine, 2008.

1642011 DARIO.

165 UNGA, World Summit Outcome, para 139.

166 UNGA, World Summit Outcome, para 139.
} 
Nevertheless, the UN enjoys immunity both in municipal and international courts even where it fails to exercise this responsibility. This immunity, as provided for under Convention on the Privileges and Immunities of the United Nations, has time and again ensured that even if the UN is held responsible for failing to prevent genocide, for instance, by the ICJ, it is not bound by such judgements because ICJ decisions are only binding to state parties before it, and the UN does not fall in that category.

\section{Conclusion}

The obligation to prevent genocide arises from a CIL obligation that binds states and the international community. Further, the UN is bound by this obligation as shown by Pillar 2 of R2P. Lastly, the procedures that are available to address the failure of the UN to uphold this obligation are non-consequential, because the UN cannot be held responsible for such a failure due to the absolute immunity it possesses.

The immunity of the UN in this regard appears to be above the jus cogens norm of the obligation to prevent genocide and, subsequently, gives a legitimate purpose for restriction of the right to access to the court. It seems that the immunity and privileges granted to the UN will continue to pose a challenge to accountability of the UN in its failure to prevent genocide. In the end, even if an obligation to prevent genocide would be violated by the UN, it would be virtually impossible to hold the UN responsible under international law. 